\title{
Synthesis of imidazo[1,5-a]pyridines via cyclocondensation of 2-(aminomethyl)pyridines with electrophilically activated nitroalkanes
}

\author{
Dmitrii A. Aksenov ${ }^{1}$, Nikolai A. Arutiunov ${ }^{1}$, Vladimir V. Maliuga ${ }^{1}$, Alexander V. Aksenov ${ }^{*}$ \\ and Michael Rubin ${ }^{*} 1,2$
}

Open Access

\author{
Full Research Paper \\ Address: \\ 1Department of Chemistry, North Caucasus Federal University, 1a \\ Pushkin St., Stavropol 355017, Russian Federation and ${ }^{2}$ Department \\ of Chemistry, University of Kansas, 1567 Irving Hill Road, Lawrence, \\ KS 66045, USA \\ Email: \\ Alexander V. Aksenov* - aaksenov@ncfu.ru; Michael Rubin* - \\ mrubin@ku.edu \\ * Corresponding author \\ Keywords: \\ cyclization; heterocycles; imidazo[1,5-a]pyridines; nitroalkanes; \\ polyphosphoric acid
}

\author{
Beilstein J. Org. Chem. 2020, 16, 2903-2910. \\ https://doi.org/10.3762/bjoc.16.239 \\ Received: 18 August 2020 \\ Accepted: 19 November 2020 \\ Published: 26 November 2020 \\ Associate Editor: I. Baxendale \\ (C) 2020 Aksenov et al.; licensee Beilstein-Institut. \\ License and terms: see end of document.
}

\begin{abstract}
Imidazo[1,5-a]pyridines were efficiently prepared via the cyclization of 2-picolylamines with nitroalkanes electrophilically activated in the presence of phosphorous acid in polyphosphoric acid (PPA) medium.
\end{abstract}

\section{Introduction}

It is hard to overstate the importance of imidazo[1,5- $a$ ]pyridines in modern organic and medicinal chemistry. Several natural alkaloids possessing this core were isolated from marine sponges, for example, cribrostatin 6 (Figure 1) [1-3]. The imidazo[1,5-a]pyridine core is also considered to be one of the privileged pharmacophoric scaffolds and can be found in many biologically active compounds, for example, the potent antitumor agent C 1311 inhibiting topoisomerase II [4-9] or pirmagrel, a cytotoxic immunosuppressant and DNA synthesis inhibitor (Figure 1) [10-12]. In addition, compounds with this struc- ture were investigated as photoluminescent sensors [13] and have been employed to generate pincer and heterocyclic carbene ligands for transition metal catalysis [14,15]. A lot of efforts have been dedicated to the development of efficient synthetic methods to access imidazo[1,5- $a$ ]pyridines, with more than 120,000 individual compounds prepared to date. Most synthetic approaches rely on various cyclocondensations of nucleophilic (2-aminomethyl)pyridine precursors, introducing a new five-membered ring. Typically, carboxylic acids [16-20], acyl anhydrides [21-23], acyl chlorides [24-27], esters [28], 
thioamides [29-31], dithionates [32,33], or thiocarbamates [34] are employed as electrophilic components, but oxidative cyclocondensations with aldehydes have also been showcased [3537]. However, given the importance of these targets, new preparative methods are still in high demand. Herein we demonstrate a new synthetic approach towards imidazo[1,5$a$ ]pyridines, taking advantage of the unusual electrophilic properties of nitroalkanes activated by PPA.<smiles>CCOC1=C(C)C(=O)c2ccn3c(C)ncc3c2C1=O</smiles>

cribrostatin 6<smiles>O=C(O)CCCCCc1cccc2cncn12</smiles>

pirmagrel (CGS 13080)<smiles>CCN(CC)CCNc1ccc2ncn3c4ccc(O)cc4c(=O)c1c23</smiles>

C 1311

Figure 1: Biologically active imidazo[1,5-a]pyridines.

\section{Results and Discussion}

Within the last few years, we have developed and implemented a number of novel synthetic methodologies in our laboratories, involving acid-mediated cascade transformations of nitroalkenes and nitroalkanes, which target materials science and medicinal chemistry applications. It was demonstrated that upon heating in polyphosphoric acid, the nitroalkanes $\mathbf{1}$ convert into the phosphorylated nitronates $\mathbf{2}$, which exhibit strong electrophilic properties. This allowed for the employment of these species in reactions wherein electron-rich arenes serve as carbon-based nucleophilies [38-40]. It was also discovered that the nucleophilic amines $\mathbf{3}$ can be successfully employed in this type of transformations as well, providing the amidinium intermediates $\mathbf{4}$, which are susceptible to a variety of subsequent cyclizations. This approach opens up a novel avenue by which to access the benzoxazoles 5 [40], benzimidazoles 6 [40,41], diazines 7 [42,43], or imidazolines 8 (Scheme 1) [44]. We have also shown that a nucleophilic attack on the phosphorylated nitronate species $\mathbf{2}$ can be carried out with the participation of $\mathrm{N}$-acylhydrazides or thiosemicarbazides to afford the 1,3,4oxadiazoles 9 [45] and the 1,3,4-thiadiazoles 10 [46], respectively (Scheme 1). Finally, it was found that the reaction of 2-hydrazinylpyridine with electrophilically activated nitroalkanes provides the corresponding triazolopyridines $\mathbf{1 1}$ (Scheme 1) [47].

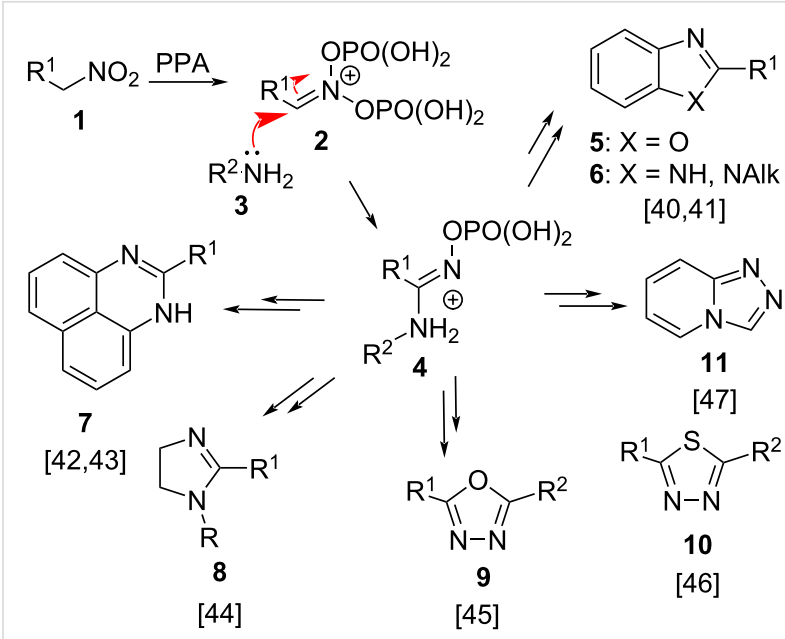

Scheme 1: Activation of nitroalkanes towards nucleophilic attack by amines.

These results prompted the desire to implement this general scheme in order to access highly important imidazo[1,5$a$ ]pyridines. It was imagined that the initial nucleophilic attack of the 2-(aminomethyl)pyridine (12) on the nitronate $\mathbf{2}$ would provide an amidinium species $\mathbf{1 3}$, which is very well suited for a 5-exo-trig cyclization involving the masked imine moiety of the pyridine ring, providing a 2,3-dihydro- $1 \mathrm{H}$-imidazo[1,5a]pyridin-4-ium ion 14. After deprotonation, the latter would form the 2,3-dihydroimidazo[1,5-a]pyridine 15, which after the elimination of $O$-phosphorylated hydroxylamine, would afford the imidazo[1,5-a]pyridines $\mathbf{1 6}$ (Scheme 2).
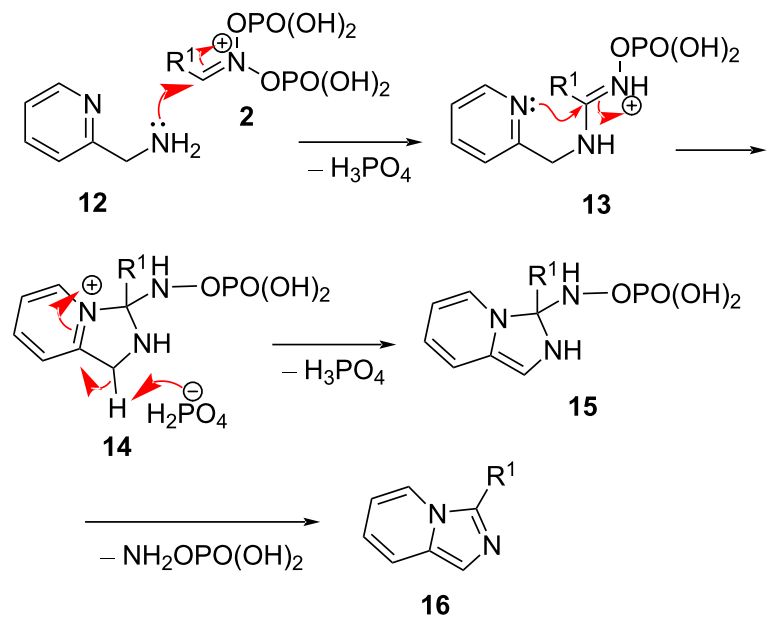

Scheme 2: Mechanistic rationale.

To test this idea, nitroethane (1a, 5 equiv) was heated at $110{ }^{\circ} \mathrm{C}$ with $85 \%$ PPA for $30 \mathrm{~min}$, and 2-(aminomethyl)pyridine (12) was added in small portions. After $3 \mathrm{~h}$ of stirring at $110{ }^{\circ} \mathrm{C}$, the 
reaction mixture was quenched with ice-cold water, neutralized with aqueous ammonia, and extracted with ethyl acetate. The organic layer was analyzed by GC and ${ }^{1} \mathrm{H}$ NMR to reveal that the desired product 16a was formed in a disappointingly low yield (Table 1, entry 1 ). Heating of the reaction mixture to $130{ }^{\circ} \mathrm{C}$, together with the employment of even more highly concentrated $87 \%$ PPA, resulted in an improved conversion, but only insignificantly so (Table 1, entries 2 and 3 ). To the contrary, an attempt to carry out the reaction in $80 \%$ PPA provided a conversion of only $6 \%$ even at $140{ }^{\circ} \mathrm{C}$ (Table 1 , entry 4 ), whereas no reaction was observed in $100 \%$ orthophosphoric acid (Table 1, entry 5). Evidently, under acidic conditions, protonation of the primary amino group in $\mathbf{1 2}$ attenuates the nucleophilicity of the molecule, rendering the attack on the relatively bulky phosphorylated nitronate 2 inefficient. To prove this, we decided to moderate the basicity of the amine function by protection with a sulfonyl group. Gratifyingly, the $N$-tosylamine 17 [48] reacted smoothly with 1-nitropropane (1b), 1-nitrobutane (1c), and 1-nitrohexane (1d) in the presence of $87 \% \mathrm{PPA}$, although this required heating to $160{ }^{\circ} \mathrm{C}$ to bring the reaction to completion. The corresponding imidazo[1,5a]pyridines $\mathbf{1 6 b}-\mathbf{d}$ were isolated in good practical yield in all three cases (Scheme 3).

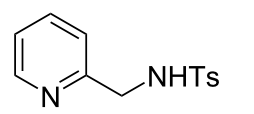

17

$$
+\mathrm{R}^{\widehat{\mathrm{NO}_{2}}} \underset{160^{\circ} \mathrm{C}, 2 \mathrm{~h}}{\stackrel{\mathrm{PPA}, 87 \%}{\longrightarrow}}
$$

1<smiles>[R]c1ncc2ccccn12</smiles>

16 1b, $16 b: R=E t, 66 \%$

1c, 16c: $\mathrm{R}=n-\mathrm{C}_{3} \mathrm{H}_{7}, 67 \%$

1d, 16d: $\mathrm{R}=n-\mathrm{C}_{5} \mathrm{H}_{11}, 64 \%$
Scheme 3: Reaction of the $N$-tosylate 17 with electrophilic nitroalkanes.
This approach, however, seems less attractive as it requires an additional step for the proper modification of the starting material. An alternative, more appealing method would capitalize on the in situ generation of a less sterically hindered, and therefore more reactive electrophilic nitronate. As we have recently demonstrated, this type of species can be efficiently generated upon the treatment of nitroalkanes with anhydrous $\mathrm{H}_{3} \mathrm{PO}_{4}$ or in combination with $87 \%$ PPA [44]. We were pleased to find that the performance of the direct transformation of $\mathbf{1 2}$ into 16a was significantly improved after doping the PPA medium with $\mathrm{H}_{3} \mathrm{PO}_{3}$. Indeed, in a mixture of $87 \% \mathrm{PPA}$ and $\mathrm{H}_{3} \mathrm{PO}_{3} 2: 1$ (mass/mass ratio), the yield reached $22 \%$ and $43 \%$ at $110{ }^{\circ} \mathrm{C}$ and $140{ }^{\circ} \mathrm{C}$, respectively (Table 1, entries 6 and 7). A further increase of the $\mathrm{H}_{3} \mathrm{PO}_{3}$ concentration and temperature improved the result. In the $1: 187 \% \mathrm{PPA} / \mathrm{H}_{3} \mathrm{PO}_{3}$ mixture at $140{ }^{\circ} \mathrm{C}$, the yield of $16 \mathrm{a}$ improved to $62 \%$ (Table 1 , entry 8 ), while at $160{ }^{\circ} \mathrm{C}$, it reached $77 \%$ (Table 1 , entry 9 ). It should be pointed out that the reported yield of $77 \%$ is the isolated yield given complete conversion, with no detected side products aside from easily removable polymeric resins.

With optimized reaction conditions in hand, we proceeded with the examination of the scope of, and tolerance towards the differrent nitroalkanes $\mathbf{1 b}-\mathbf{f}$. Overall, the reaction proceeded smoothly, providing moderate yields of the corresponding imidazo[1,5- $a$ ]pyridines 16b-f (Scheme 4). The only exception to this general trend was the reaction with $\alpha$-nitrotoluene (1g), which proceeded sluggishly and provided a disappointingly low yield of 3-phenylimidazo[1,5-a]pyridine (16g, Scheme 4).

Next, the scope of nucleophilic substrates was investigated. The readily available 2-(aminomethyl)quinolines $\mathbf{1 8}$ bearing various substituents at C-5, C-6, and C-1' were tested in reactions with the nitroalkanes 1a-c and 1e. All of these reactions proceeded uneventfully, affording the corresponding imidazo[1,5$a$ ]pyridines in moderate to good yield (Scheme 5).

\begin{tabular}{|c|c|c|c|}
\hline entry & medium $^{a}$ & $T,{ }^{\circ} \mathrm{C}(t, \mathrm{~h})$ & yield, \%b \\
\hline 1 & PPA $85 \% 1 \mathrm{~g} / \mathrm{mmol}$ & $110(3)$ & 4 \\
\hline 2 & PPA $85 \% 1 \mathrm{~g} / \mathrm{mmol}$ & $130(3)$ & 13 \\
\hline 3 & PPA $87 \% 1 \mathrm{~g} / \mathrm{mmol}$ & $130(3)$ & 15 \\
\hline 4 & PPA $80 \%$ & $140(3)$ & 6 \\
\hline 5 & $\mathrm{H}_{3} \mathrm{PO}_{4} 100 \%$ & $140(5)$ & 0 \\
\hline 6 & $\mathrm{PPA} 87 \% 0.5 \mathrm{~g} / \mathrm{H}_{3} \mathrm{PO}_{3} 0.25 \mathrm{~g} / \mathrm{mmol}$ & $110(5)$ & 22 \\
\hline 7 & $\mathrm{PPA} 87 \% 0.5 \mathrm{~g} / \mathrm{H}_{3} \mathrm{PO}_{3} 0.25 \mathrm{~g} / \mathrm{mmol}$ & $140(2)$ & 43 \\
\hline 8 & $\mathrm{PPA} 87 \% 0.5 \mathrm{~g} / \mathrm{H}_{3} \mathrm{PO}_{3} 0.5 \mathrm{~g} / \mathrm{mmol}$ & $140(1.5)$ & 62 \\
\hline 9 & PPA $87 \% 0.5 \mathrm{~g} / \mathrm{H}_{3} \mathrm{PO}_{3} 0.5 \mathrm{~g} / \mathrm{mmol}$ & $160(2)$ & $77^{c}$ \\
\hline
\end{tabular}

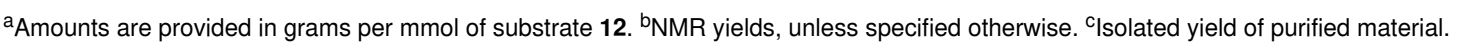




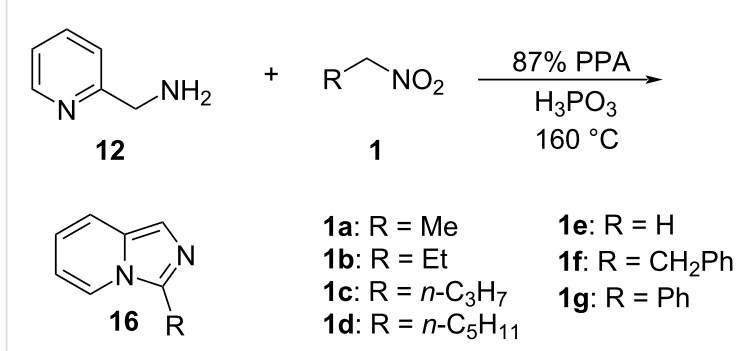

16a: $77 \%$ 16b: $53 \%$ 16c: $59 \%$<smiles>c1ccc(-c2ncc3ccccn23)cc1</smiles>

16e: $62 \% \quad 16 f: 54 \% \quad 16 g: 12 \%$

Scheme 4: Reaction of 2-(aminomethyl)pyridine (12) with electrophilic nitroalkanes.<smiles></smiles>

$$
\begin{array}{cl}
\mathrm{R}^{4} \widehat{N O}_{2} & \multicolumn{1}{c}{87 \% \mathrm{PPA}} \\
& \begin{array}{c}
\mathrm{H}_{3} \mathrm{PO}_{3} \\
160^{\circ} \mathrm{C}
\end{array} \\
\text { 1a: } \mathrm{R}^{4}=\mathrm{Me} & 1 \mathrm{c}: \mathrm{R}^{4}=n-\mathrm{C}_{3} \mathrm{H}_{7} \\
\text { 1b: } \mathrm{R}^{4}=\mathrm{Et} & 1 \mathrm{e}: \mathrm{R}^{4}=\mathrm{H}
\end{array}
$$

18a: $R^{1}=R^{2}=R^{3}=H$ 18b: $\mathrm{R}^{1}=n-\mathrm{C}_{3} \mathrm{H}_{7} ; \mathrm{R}^{2}=\mathrm{R}^{3}=\mathrm{H}$ 18c: $R^{1}=H ; R^{2}=B r ; R^{3}=H$ 18d: $R^{1}=H ; R^{2}=O M e, R^{3}=B r$ 19<smiles>Cc1ncc2ccc3ccccc3n12</smiles>

19aa: $61 \%$<smiles>CCc1ncc2ccc3ccccc3n12</smiles>

19ab: $46 \%$

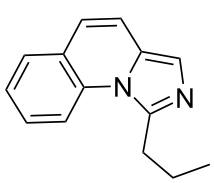

19ac: $56 \%$<smiles>c1ccc2c(c1)ccc1cncn12</smiles>

19ae: $83 \%$<smiles>O=S(=O)(O)c1cccc2c1C=CCN2</smiles>

19ce: $59 \%$

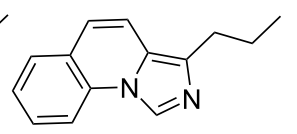

19be: $48 \%$<smiles>Brc1ccc2c(ccc3cncn32)c1</smiles><smiles>COc1ccc2c(ccc3cncn32)c1Br</smiles>

19de: $72 \%$
Scheme 5: Reaction of the 2-(aminomethyl)quinolines 18 with electrophilic nitroalkanes.
We also attempted to address the issue of the low reactivity of $\alpha$-nitrotoluene (1g). We have previously demonstrated that in the reaction with nucleophilic 1,2-diamines, $\alpha$-nitroacetophenone (1h) can be employed as a much more versatile synthetic equivalent to afford the corresponding 2-phenylimidazolines [44]. Gratifyingly, this approach also worked well with the substrates 12, 18a, and 18b. The corresponding imidazo[1,5$a$ ]pyridines $\mathbf{1 6 g}, \mathbf{1 9} \mathrm{ag}$, and $\mathbf{1 8 b g}$ were obtained in a highly efficient manner (Scheme 6). In addition, $\alpha$-nitroacetic ester (1i) was probed as an electrophile in the reaction with substrate $\mathbf{1 2}$ in order to demonstrate that the phosphorylated nitronate function is a superior electrophile in comparison to the ester function. Indeed, this bielectrophilic reagent reacted only at the nitro group, providing the amide $\mathbf{2 0}$ as the sole product. The yield was quite marginal, primarily due to decomposition of the fragile ester functionality under the harsh reaction conditions employed. Unfortunately, cyclization did not take place (Scheme 6).

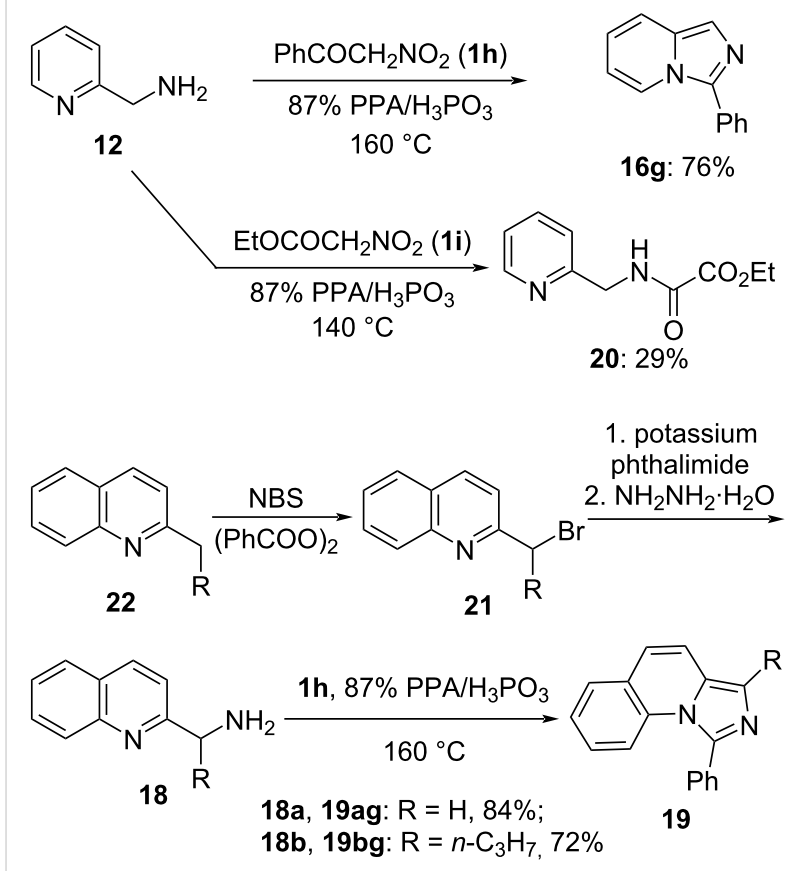

Scheme 6: Reactivity of $\alpha$-nitroacetophenone (1h) and $\alpha$-nitroacetic ester (1i).

\section{Conclusion}

In conclusion, a new method to access imidazo[1,5- $a$ ]pyridines via the unusual cyclization of 2-(aminomethyl)pyridines or 2-(aminomethyl)quinolines with nitroalkanes that are electrophilically activated in the presence of phosphorous acid in polyphosphoric acid medium was described. The reaction is quite sensitive to steric factors and affords medium to good yields of the products, although relatively harsh reaction conditions are required. The introduction of a phenyl substituent 
proved problematic in the reactions involving $\alpha$-nitrotoluene, but this could be easily circumvented by replacing it with the better-performing $\alpha$-nitroacetophenone (1h).

\section{Experimental}

General information. ${ }^{1} \mathrm{H}$ and ${ }^{13} \mathrm{C}$ NMR spectra were recorded on a Bruker Avance-III spectrometer (400 or $100 \mathrm{MHz}$, respectively) equipped with a $\mathrm{BBO}$ probe in $\mathrm{CDCl}_{3}$ or DMSO- $d_{6}$, using TMS as an internal standard. High-resolution mass spectra were obtained using a Bruker Maxis spectrometer (electrospray ionization, $\mathrm{MeCN}$ solution, using $\mathrm{HCO}_{2} \mathrm{Na} / \mathrm{HCO}_{2} \mathrm{H}$ for calibration). Melting points were measured with a Stuart smp30 apparatus. All reactions were performed in oven-dried flasks equipped with reflux condensers and magnetic stir bars. All reactions were followed by thin-layer chromatography (TLC) using Silufol UV-254 plates, which were visualized under UV light $(254 \mathrm{~nm})$, with acetone, hexane/acetone, or hexane/ ethanol/acetone mixtures as eluent. Polyphosphoric acid (87\%) was obtained by dissolving a precise amount of $\mathrm{P}_{2} \mathrm{O}_{5}$ in $85 \%$ orthophosphoric acid according to the published protocols $[49,50]$. All other reagents and solvents were purchased from commercial vendors and used as received.

\section{1-(6-Bromoquinolin-2-yl)methanamine (18c): typical procedure 1}

First, 6-bromo-2-(bromomethyl)quinoline (21c) was prepared from commercially available 6-bromo-2-methylquinoline (22c, via radical bromination in the presence of NBS and dibenzoyl peroxide [51]. To this end, the methylquinoline 22c (3.33 g, $15 \mathrm{mmol}$ ) was dissolved in carbon tetrachloride $(30 \mathrm{~mL})$, and $\mathrm{N}$-bromosuccinimide (2.94 g, $16.5 \mathrm{mmol})$ was added, followed by dibenzoyl peroxide (194 $\mathrm{mg}, 0.80 \mathrm{mmol}$ ). The mixture was refluxed for $5-7 \mathrm{~h}$ while the reaction progress was monitored by TLC. Upon completion, the reaction mixture was cooled to room temperature, the formed precipitate of succinimide was filtered off, and the filtrate was concentrated in vacuum. The crude product was purified by flash column chromatography eluting with EtOAc/petroleum ether 1:6. Then, the amine was afforded via a Gabriel synthesis using a modified protocol described in the literature [52]. To a stirred solution of 6-bromo-2(bromomethyl)quinoline $(3.01 \mathrm{~g}, 10 \mathrm{mmol})$ in DMF $(16 \mathrm{~mL})$ was added potassium phthalimide $(1.85 \mathrm{~g}, 10 \mathrm{mmol})$ in portions. The mixture was stirred at room temperature for $5 \mathrm{~h}$. Then, water $(30 \mathrm{~mL}$ ) was added, and the formed precipitate was collected by filtration and washed with water. Recrystallization from ethanol afforded colorless crystals of intermediate 2-((6bromoquinolin-2-yl)methyl)isoindoline-1,3-dione. This material (3.05 g, $8.3 \mathrm{mmol})$ was suspended in ethanol, and hydrazine hydrate $(50 \%, 1.0 \mathrm{~g}, 10 \mathrm{mmol})$ was added. The reaction mixture was refluxed for $5 \mathrm{~h}$ and then cooled down to $0{ }^{\circ} \mathrm{C}$. The precipitated phthalyl hydrazide was filtered off and rinsed several times with cold ethanol. The combined filtrates were concentrated under reduced pressure to provide the crude amine, which was purified by flash column chromatography on silica gel, eluting with a mixture of dichloromethane/ethanol/triethylamine, gradient 80:10:1-80:30:1. The titled compound was obtained as colorless powder, overall yield 80\% (1.89 g, $8.00 \mathrm{mmol})$. Overall yield $1.89 \mathrm{~g}(8.00 \mathrm{mmol}, 80 \%) \mathrm{Mp}$ 73-74 ${ }^{\circ} \mathrm{C} ; R_{\mathrm{f}} 0.50\left(\mathrm{CH}_{2} \mathrm{Cl}_{2} / \mathrm{EtOH} \mathrm{NEt}_{3} 80: 30: 1, \mathrm{v} / \mathrm{v} / \mathrm{v}\right)$; ${ }^{1} \mathrm{H}$ NMR $\left(400 \mathrm{MHz}, \mathrm{CDCl}_{3}\right) \delta 8.01(\mathrm{~d}, J=8.5 \mathrm{~Hz}, 1 \mathrm{H}, 9-\mathrm{H})$, $7.95(\mathrm{~d}, J=1.0 \mathrm{~Hz}, 1 \mathrm{H}, 4-\mathrm{H}), 7.91$ (d, $J=9.0 \mathrm{~Hz}, 1 \mathrm{H}, 6-\mathrm{H})$, $7.75(\mathrm{dd}, J=8.8 ; 1.5 \mathrm{~Hz}, 1 \mathrm{H}, 8-\mathrm{H}), 7.41(\mathrm{~d}, J=8.5 \mathrm{~Hz}, 1 \mathrm{H}$, $3-\mathrm{H}), 4.17\left(\mathrm{~s}, 2 \mathrm{H}, \mathrm{CH}_{2}\right), 2.49(\mathrm{~s}, 2 \mathrm{H}, \mathrm{NH}) ;{ }^{13} \mathrm{C} \mathrm{NMR}$ $\left(101 \mathrm{MHz} \mathrm{CDCl}_{3}\right) \delta 162.2,146.4,135.7,133.1,130.8,129.8$, 128.5, 120.8, 120.0, 48.1; ATR-FTIR (ZnSe) $v_{\max }: 3293,2920$, 2597, 1908, 1735, 1594, 1489, 1314, 1186, $1061 \mathrm{~cm}^{-1}$; HRESIMS (TOF) $\mathrm{m} / \mathrm{z}:[\mathrm{M}+\mathrm{H}]^{+}$calcd for $\mathrm{C}_{10} \mathrm{H}_{10} \mathrm{BrN}_{2}$, 237.0022; found, 237.0022.

\section{3-Methylimidazo[1,5-a]pyridine (16a) [53]: typical procedure 2}

A $5 \mathrm{~mL}$ Erlenmeyer flask equipped with a magnetic stirring bar was charged with nitroethane (1a, $150 \mathrm{mg}, 2.00 \mathrm{mmol})$, 2-picolylamine (12, $108 \mathrm{mg}, 1.00 \mathrm{mmol}), 87 \%$ polyphosphoric acid (500 mg), and phosphorous acid (500 mg). The flask was capped with a septum, placed into an oil bath preheated to $160{ }^{\circ} \mathrm{C}$, and stirred for $2 \mathrm{~h}$. Then, the mixture was poured into ice-cold water $(20 \mathrm{~mL})$, neutralized with aqueous ammonia, and extracted with ethyl acetate $(4 \times 20 \mathrm{~mL})$. The combined organic extracts were concentrated, the residue dried in vacuum, and then purified by preparative column chromatography on silica gel, eluting with a mixture of petroleum ether and ethyl acetate. The titled compound was obtained as yellow solid (lit. [53] yellow crystals), yield $77 \%$ (101 $\mathrm{mg}, 0.77 \mathrm{mmol}) . \mathrm{Mp} \mathrm{50-52}{ }^{\circ} \mathrm{C}$ (lit. [53] mp 49-50 ${ }^{\circ} \mathrm{C}$, cyclohexane); $R_{\mathrm{f}} 0.32$ (EtOAc); ${ }^{1} \mathrm{H}$ NMR (400 MHz, DMSO- $d_{6}$ ) $\delta 8.04$ (dd, $J=7.1 ; 1.0 \mathrm{~Hz}, 1 \mathrm{H}$, 5-H), $7.48(\mathrm{dt}, J=9.1 ; 1.1 \mathrm{~Hz}, 1 \mathrm{H}, 8-\mathrm{H}), 7.24(\mathrm{~d}, J=0.6 \mathrm{~Hz}$, $1 \mathrm{H}, 1-\mathrm{H}$ ), 6.69 (ddd, $J=9.1 ; 6.3 ; 0.8 \mathrm{~Hz}, 1 \mathrm{H}, 7-\mathrm{H}), 6.61$ (ddd, $1 \mathrm{H}, 6-\mathrm{H}), 2.57\left(\mathrm{~s}, 3 \mathrm{H}, \mathrm{CH}_{3}\right) ;{ }^{13} \mathrm{C}$ NMR (101 MHz, DMSO- $\left.d_{6}\right) \delta$ $134.8,129.7,121.7,117.9,117.72,117.69,111.8,12.21$. ATRFTIR (ZnSe) $v_{\max }: 3041,2924,2857,1635,1494,1442,1400$, 1357, 1322, 1267, 1248, $1170 \mathrm{~cm}^{-1}$; HRESIMS (TOF) $\mathrm{m} / \mathrm{z}$ : $[\mathrm{M}+\mathrm{H}]^{+}$calcd for $\mathrm{C}_{8} \mathrm{H}_{9} \mathrm{~N}_{2}, 133.0760$; found, 133.0758 .

\section{3-Ethylimidazo[1,5-a]pyridine (16b) [54]: typical procedure 3}

A $5 \mathrm{~mL}$ Erlenmeyer flask equipped with a magnetic stirring bar was charged with 1-nitropropane (1b, $178 \mathrm{mg}, 2.00 \mathrm{mmol})$, 4-methyl- $N$-(pyridin-2-ylmethyl)benzenesulfonamide (17, $262 \mathrm{mg}, 1.00 \mathrm{mmol})$, and 87\% polyphosphoric acid $(2.00 \mathrm{~g})$. The flask was capped with a septum, placed into an oil bath preheated to $160{ }^{\circ} \mathrm{C}$, and stirred for $2 \mathrm{~h}$. Upon reaction comple- 
tion, the aqueous work-up, isolation, and purification of the product was performed in the same way as described in the typical procedure 1 . The titled compound was obtained as yellow solid (lit. [54] yellow crystals), yield 66\% (96 mg, $0.66 \mathrm{mmol}$ ). Alternatively, the same compound was obtained via the typical procedure 1 starting with 1-nitropropane (1b, $178 \mathrm{mg}, 2.00 \mathrm{mmol})$ and 2-picolylamine (12, $108 \mathrm{mg}$, $1.00 \mathrm{mmol}$ ), yield 53\% (77 mg, $0.53 \mathrm{mmol})$. Mp 59-62 ${ }^{\circ} \mathrm{C}$ (lit. [54] $\mathrm{mp} 61{ }^{\circ} \mathrm{C}$, cyclohexane); $R_{\mathrm{f}} 0.27$ (EtOAc/petroleum ether $1: 1, \mathrm{v} / \mathrm{v}) ;{ }^{1} \mathrm{H}$ NMR $\left(400 \mathrm{MHz}, \mathrm{DMSO}-d_{6}\right) \delta 8.10(\mathrm{~d}, J=6.6 \mathrm{~Hz}$, $1 \mathrm{H}, 5-\mathrm{H}), 7.49$ (d, $J=8.9 \mathrm{~Hz}, 1 \mathrm{H}, 8-\mathrm{H}), 7.26(\mathrm{~s}, 1 \mathrm{H}, 1-\mathrm{H}), 6.70$ (t, 1H, 7-H), 6.61 (t, $J=6.0 \mathrm{~Hz}, 1 \mathrm{H}, 6-\mathrm{H}), 2.96$ (dd, $J=14.7$; $\left.7.3 \mathrm{~Hz}, 2 \mathrm{H}, \mathrm{CH}_{2}, 3-\mathrm{Et}\right), 1.30$ (t, $\left.J=7.4 \mathrm{~Hz}, 3 \mathrm{H}, \mathrm{CH}_{3}, 3-\mathrm{Et}\right)$; ${ }^{13} \mathrm{C}$ NMR (101 MHz, DMSO-d $\left.d_{6}\right) \delta 139.5,129.8,121.6,118.1$, 117.9, 117.6, 111.8, 19.1, 11.2; ATR-FTIR (ZnSe) $v_{\max }: 2975$, 1638, 1504, 1491, 1454, 1367, 1326, $1241 \mathrm{~cm}^{-1}$; HRESIMS (TOF) $m / z:[\mathrm{M}+\mathrm{H}]^{+}$calcd for $\mathrm{C}_{9} \mathrm{H}_{11} \mathrm{~N}_{2}, 147.0917$; found, 147.0913 .

\section{3-Phenylimidazo[1,5-a]pyridine (16g) [36]: typical procedure 4}

A $5 \mathrm{~mL}$ Erlenmeyer flask equipped with a magnetic stirring bar was charged with 2-nitro-1-phenylethan-1-one (1h, $330 \mathrm{mg}$, $2.00 \mathrm{mmol}$ ), 2-picolylamine (12, $108 \mathrm{mg}, 1.00 \mathrm{mmol}), 87 \%$ polyphosphoric acid (500 mg), and phosphorous acid (500 mg). The flask was capped with a septum, placed into an oil bath preheated to $160{ }^{\circ} \mathrm{C}$, and stirred for $2 \mathrm{~h}$. Upon reaction completion, the aqueous work-up, isolation, and purification of the product were performed in the same way as described in the typical procedure 1 . The titled compound was obtained as yellow solid (lit. [36] yellow solid), yield 76\% (147 mg, $0.76 \mathrm{mmol})$. Alternatively, the same compound was obtained via the typical procedure 2 starting with (nitromethyl)benzene (274 $\mathrm{mg}, 2.00 \mathrm{mmol})$ and 2-picolylamine (12, $108 \mathrm{mg}$, $1.00 \mathrm{mmol}$ ), yield $12 \%$ (24 mg, $0.12 \mathrm{mmol}$ ). Mp $108-110{ }^{\circ} \mathrm{C}$ (lit. [36] mp $105-110^{\circ} \mathrm{C}$ ); $R_{\mathrm{f}} 0.51$ (EtOAc/petroleum ether $1: 1$, $\mathrm{v} / \mathrm{v}) ;{ }^{1} \mathrm{H}$ NMR $\left(400 \mathrm{MHz}, \mathrm{DMSO}-d_{6}\right) \delta 8.44(\mathrm{~d}, J=7.2 \mathrm{~Hz}, 1 \mathrm{H}$, $5-\mathrm{H}), 7.83(\mathrm{~d}, J=7.3 \mathrm{~Hz}, 2 \mathrm{H}, 2,6-\mathrm{H} 3-\mathrm{Ph}), 7.64(\mathrm{~d}, J=9.1 \mathrm{~Hz}$, $1 \mathrm{H}, 8-\mathrm{H}), 7.55$ (dd, $J=9.1 ; 6.1 \mathrm{~Hz}, 3 \mathrm{H}, 3,4,5-\mathrm{H} 3-\mathrm{Ph}), 7.46$ (t, $J=7.4 \mathrm{~Hz}, 1 \mathrm{H}, 1-\mathrm{H}), 6.83(\mathrm{dd}, J=9.0 ; 6.4 \mathrm{~Hz}, 1 \mathrm{H}, 7-\mathrm{H}), 6.71$ $(\mathrm{t}, J=6.8 \mathrm{~Hz}, 1 \mathrm{H}, 6-\mathrm{H}) ;{ }^{13} \mathrm{C}$ NMR $\left(101 \mathrm{MHz}, \mathrm{DMSO}-d_{6}\right) \delta$ 137.3, 131.4, 130.2, 129.0 (2C), 128.4, 127.6 (2C), 121.8, 120.4, 119.3, 118.5, 113.5; ATR-FTIR (ZnSe) $v_{\max }: 3066$, 1749, 1676, 1603, 1473, 1458, 1433, 1358, 1305, 1251, 1267, $1120 \mathrm{~cm}^{-1}$; HRESIMS (TOF) $\mathrm{m} / \mathrm{z}:[\mathrm{M}+\mathrm{H}]^{+}$calcd for $\mathrm{C}_{13} \mathrm{H}_{11} \mathrm{~N}_{2}$, 195.0917; found, 195.0918.

\section{6-Bromo-7-methoxyimidazo[1,5-a]quinoline (19de)}

The title compound was obtained via the typical procedure 2, starting from nitromethane (1e, $122 \mathrm{mg}, 2.00 \mathrm{mmol})$ and (5-bromo-6-methoxyquinolin-2-yl)methanamine (18d, $267 \mathrm{mg}$, $1.00 \mathrm{mmol}$ ). Pale yellow solid, yield 72\% (198 mg, $0.72 \mathrm{mmol}$ ). Mp 177-179 ${ }^{\circ} \mathrm{C} ; R_{\mathrm{f}} 0.43$ (acetone/petroleum ether $1: 1, \mathrm{v} / \mathrm{v}$ ); ${ }^{1} \mathrm{H}$ NMR (400 MHz, DMSO- $\left.d_{6}\right) \delta 9.11(\mathrm{~d}, J=0.8 \mathrm{~Hz}, 1 \mathrm{H}$, $1-\mathrm{H}), 8.42(\mathrm{dd}, J=9.2 ; 0.7 \mathrm{~Hz}, 1 \mathrm{H}, 9-\mathrm{H}), 7.48(\mathrm{~s}, 1 \mathrm{H}, 3-\mathrm{H})$, $7.45(\mathrm{~d}, J=9.2 \mathrm{~Hz}, 1 \mathrm{H}, 4-\mathrm{H}), 7.44(\mathrm{~s}, 1 \mathrm{H}, 5-\mathrm{H}), 7.37$ (d, $J=$ $9.8 \mathrm{~Hz}, 1 \mathrm{H}, 8-\mathrm{H}), 3.96\left(\mathrm{~s}, 3 \mathrm{H}, \mathrm{CH}_{3}\right) ;{ }^{13} \mathrm{C} \mathrm{NMR}(101 \mathrm{MHz}$, DMSO- $\left.d_{6}\right) \delta 153.4,129.7,127.4,125.7,124.0,123.0,119.3$, 118.8, 115.9, 113.4, 109.9, 56.9; ATR-FTIR (ZnSe) $v_{\max }: 3106$, 2938, 2846, 1603, 1466, 1436, 1423, 1273, 1208, 1129, $1069 \mathrm{~cm}^{-1}$; HRESIMS (TOF) $\mathrm{m} / \mathrm{z}:[\mathrm{M}+\mathrm{H}]^{+}$calcd for $\mathrm{C}_{12} \mathrm{H}_{10} \mathrm{BrN}_{2} \mathrm{O}, 276.9971$; found, 276.9974.

\section{Supporting Information}

\section{Supporting Information File 1}

Synthetic procedures and characterization data for compounds 16c-f, 18b and 18d, 19aa, 19ab, 19ac, 19ag, 19bb, 19bg, 19ce, and 20 as well as ${ }^{1} \mathrm{H}$ NMR, ${ }^{13} \mathrm{C}$ NMR, and HRMS spectral charts for all new compounds. [https://www.beilstein-journals.org/bjoc/content/ supplementary/1860-5397-16-239-S1.pdf]

\section{Funding}

This work was supported by the Russian Foundation for Basic Research (grant \#19-03-00308a) and a grant from the Ministry of Education and Science of the Russian Federation (grant \#0795-2020-0031).

\section{ORCID ${ }^{\circledR}$ iDs}

Dmitrii A. Aksenov - https://orcid.org/0000-0002-0727-9652 Nikolai A. Arutiunov - https://orcid.org/0000-0003-2675-9093 Vladimir V. Maliuga - https://orcid.org/0000-0002-2702-5684 Alexander V. Aksenov - https://orcid.org/0000-0002-6644-9949 Michael Rubin - https://orcid.org/0000-0002-1668-9311

\section{References}

1. Calcul, L.; Longeon, A.; Al Mourabit, A.; Guyot, M.; Bourguet-Kondracki, M.-L. Tetrahedron 2003, 59, 6539-6544. doi:10.1016/s0040-4020(03)01069-x

2. Pettit, G. R.; Collins, J. C.; Knight, J. C.; Herald, D. L.; Nieman, R. A.; Williams, M. D.; Pettit, R. K. J. Nat. Prod. 2003, 66, 544-547. doi:10.1021/np020012t

3. Yu, H.-B.; Yang, F.; Sun, F.; Ma, G.-Y.; Gan, J.-H.; Hu, W.-Z.; Han, B.-N.; Jiao, W.-H.; Lin, H.-W. J. Nat. Prod. 2014, 77, 2124-2129. doi:10.1021/np500583z

4. Augustin, E.; Pawłowska, M.; Polewska, J.; Potega, A.; Mazerska, Z. Cell Biol. Int. 2013, 37, 109-120. doi:10.1002/cbin.10018

5. Isambert, N.; Campone, M.; Bourbouloux, E.; Drouin, M.; Major, A.; Yin, W.; Loadman, P.; Capizzi, R.; Grieshaber, C.; Fumoleau, P. Eur. J. Cancer 2010, 46, 729-734. doi:10.1016/j.ejca.2009.12.005 
6. Paradziej-Łukowicz, J.; Skwarska, A.; Peszyńska-Sularz, G.; Brillowska-Dąbrowska, A.; Konopa, J. Cancer Biol. Ther. 2011, 12 , 586-597. doi:10.4161/cbt.12.7.15980

7. Polewska, J.; Skwarska, A.; Augustin, E.; Konopa, J. J. Pharmacol. Exp. Ther. 2013, 346, 393-405. doi:10.1124/jpet.113.203851

8. Skwarska, A.; Augustin, E.; Konopa, J. Apoptosis 2007, 12, 2245-2257. doi:10.1007/s10495-007-0144-y

9. Zaffaroni, N.; De Marco, C.; Villa, R.; Riboldi, S.; Daidone, M. G.; Double, J. A. Eur. J. Cancer 2001, 37, 1953-1962. doi:10.1016/s0959-8049(01)00227-1

10. Gresele, P.; Blockmans, D.; Deckmyn, H.; Vermylen, J. J. Pharmacol. Exp. Ther. 1988, 246, 301-307.

11. Huang, A.; Sun, D.; Koller, A. Hypertension 1993, 22, 913-921. doi:10.1161/01.hyp.22.6.913

12. Reilly, I. A.; Doran, J. B.; Smith, B.; FitzGerald, G. A. Circulation 1986, 73, 1300-1309. doi:10.1161/01.cir.73.6.1300

13. Volpi, G.; Garino, C.; Priola, E.; Magistris, C.; Chierotti, M. R.; Barolo, C. Dyes Pigm. 2019, 171, 107713. doi:10.1016/j.dyepig.2019.107713

14. Cui, Y.; Ge, Y.; Li, Y.; Tao, J.; Yao, J.; Dong, Y. Struct. Chem. 2020, 31, 547-555. doi:10.1007/s11224-019-01429-3

15. Park, D.-A.; Byun, S.; Ryu, J. Y.; Lee, J.; Lee, J.; Hong, S. ACS Catal. 2020, 10, 5443-5453. doi:10.1021/acscatal.0c00802

16. Volpi, G.; Lace, B.; Garino, C.; Priola, E.; Artuso, E.; Cerreia Vioglio, P.; Barolo, C.; Fin, A.; Genre, A.; Prandi, C. Dyes Pigm. 2018, 157, 298-304. doi:10.1016/j.dyepig.2018.04.037

17. Volpi, G.; Garino, C.; Priola, E.; Diana, E.; Gobetto, R.; Buscaino, R.; Viscardi, G.; Barolo, C. Dyes Pigm. 2017, 143, 284-290. doi:10.1016/j.dyepig.2017.04.034

18. Singh, D.; Kumar, V.; Devi, N.; Malakar, C. C.; Shankar, R.; Singh, V. Adv. Synth. Catal. 2017, 359, 1213-1226. doi:10.1002/adsc.201600970

19. Buil, M. A.; Calbet, M.; Castillo, M.; Castro, J.; Esteve, C.; Ferrer, M.; Forns, P.; González, J.; López, S.; Roberts, R. S.; Sevilla, S.; Vidal, B.; Vidal, L.; Vilaseca, P. Eur. J. Med. Chem. 2016, 113, 102-133. doi:10.1016/j.ejmech.2016.02.023

20. Chino, A.; Masuda, N.; Amano, Y.; Honbou, K.; Mihara, T.; Yamazaki, M.; Tomishima, M. Bioorg. Med. Chem. 2014, 22, 3515-3526. doi:10.1016/j.bmc.2014.04.023

21. Amini-Rentsch, L.; Vanoli, E.; Richard-Bildstein, S.; Marti, R.; Vilé, G. Ind. Eng. Chem. Res. 2019, 58, 10164-10171. doi:10.1021/acs.iecr.9b01906

22. Bosch, P.; García, V.; Bilen, B. S.; Sucunza, D.; Domingo, A.; Mendicuti, F.; Vaquero, J. J. Dyes Pigm. 2017, 138, 135-146. doi:10.1016/j.dyepig.2016.11.041

23. Tverdiy, D. O.; Chekanov, M. O.; Savitskiy, P. V.; Syniugin, A. R.; Yarmoliuk, S. M.; Fokin, A. A. Synthesis 2016, 48, 4269-4277. doi:10.1055/s-0035-1561489

24. Kurhade, S.; Konstantinidou, M.; Sutanto, F.; Kurpiewska, K.; Kalinowska-Tłuścik, J.; Dömling, A. Eur. J. Org. Chem. 2019, 2029-2034. doi:10.1002/ejoc.201801880

25. Nirogi, R.; Mohammed, A. R.; Shinde, A. K.; Bogaraju, N.; Gagginapalli, S. R.; Ravella, S. R.; Kota, L.; Bhyrapuneni, G.; Muddana, N. R.; Benade, V.; Palacharla, R. C.; Jayarajan, P.; Subramanian, R.; Goyal, V. K. Eur. J. Med. Chem. 2015, 103, 289-301. doi:10.1016/j.ejmech.2015.08.051
26. Roberts, L. R.; Bradley, P. A.; Bunnage, M. E.; England, K. S.; Fairman, D.; Fobian, Y. M.; Fox, D. N. A.; Gymer, G. E.; Heasley, S. E.; Molette, J.; Smith, G. L.; Schmidt, M. A.; Tones, M. A.; Dack, K. N. Bioorg. Med. Chem. Lett. 2011, 21, 6515-6518. doi:10.1016/j.bmcl.2011.08.071

27. Trotter, B. W.; Nanda, K. K.; Burgey, C. S.; Potteiger, C. M.; Deng, J. Z.; Green, A. I.; Hartnett, J. C.; Kett, N. R.; Wu, Z.; Henze, D. A.; Della Penna, K.; Desai, R.; Leitl, M. D.; Lemaire, W.; White, R. B.; Yeh, S.; Urban, M. O.; Kane, S. A.; Hartman, G. D.; Bilodeau, M. T. Bioorg. Med. Chem. Lett. 2011, 21, 2354-2358. doi:10.1016/j.bmcl.2011.02.082

28. Kurhade, S.; Diekstra, E.; Sutanto, F.; Kurpiewska, K.; Kalinowska-Tłuścik, J.; Dömling, A. Org. Lett. 2018, 20, 3871-3874. doi:10.1021/acs.orglett.8b01452

29. Fuse, S.; Ohuchi, T.; Asawa, Y.; Sato, S.; Nakamura, H. Bioorg. Med. Chem. Lett. 2016, 26, 5887-5890. doi:10.1016/j.bmcl.2016.11.009

30. Murai, T.; Nagaya, E.; Shibahara, F.; Maruyama, T. Org. Biomol. Chem. 2012, 10, 4943-4953. doi:10.1039/c2ob25438g

31. Tahara, S.; Shibahara, F.; Maruyama, T.; Murai, T. Chem. Commun. 2009, 7009-7011. doi:10.1039/b910172a

32. Ramesha, A. B.; Pavan Kumar, C. S.; Sandhya, N. C.; Kumara, M. N.; Mantelingu, K.; Rangappa, K. S. RSC Adv. 2016, 6, 48375-48378. doi:10.1039/c6ra03771b

33. Ramesha, A. B.; Sandhya, N. C.; Pavan Kumar, C. S.; Hiremath, M.; Mantelingu, K.; Rangappa, K. S. New J. Chem. 2016, 40, 7637-7642. doi:10.1039/c6nj01038e

34. Späth, A.; Gonschor, J.; König, B. Monatsh. Chem. 2011, 142, 1289-1308. doi:10.1007/s00706-011-0660-x

35. Bori, J.; Behera, N.; Mahata, S.; Manivannan, V. ChemistrySelect 2017, 2, 11727-11731. doi:10.1002/slct.201702420

36. Li, M.; Xie, Y.; Ye, Y.; Zou, Y.; Jiang, H.; Zeng, W. Org. Lett. 2014, 16, 6232-6235. doi:10.1021/ol503165b

37. Shibahara, F.; Sugiura, R.; Yamaguchi, E.; Kitagawa, A.; Murai, T. J. Org. Chem. 2009, 74, 3566-3568. doi:10.1021/jo900415y

38. Aksenov, A. V.; Aksenov, N. A.; Nadein, O. N.; Aksenova, I. V. Synlett 2010, 2628-2630. doi:10.1055/s-0030-1258767

39. Aksenov, A. V.; Aksenov, N. A.; Orazova, N. A.; Aksenov, D. A.; Dmitriev, M. V.; Rubin, M. RSC Adv. 2015, 5, 84849-84855. doi:10.1039/c5ra17668a

40. Aksenov, N. A.; Aksenov, A. V.; Nadein, O. N.; Aksenov, D. A.; Smirnov, A. N.; Rubin, M. RSC Adv. 2015, 5, 71620-71626. doi:10.1039/c5ra15128g

41. Aksenov, A. V.; Smirnov, A. N.; Aksenov, N. A.; Bijieva, A. S.; Aksenova, I. V.; Rubin, M. Org. Biomol. Chem. 2015, 13, 4289-4295. doi:10.1039/c5ob00131e

42. Aksenov, A. V.; Aksenov, N. A.; Ovcharov, D. S.; Aksenov, D. A.; Griaznov, G.; Voskressensky, L. G.; Rubin, M. RSC Adv. 2016, 6, 82425-82431. doi:10.1039/c6ra17269e

43. Aksenov, A. V.; Ovcharov, D. S.; Aksenov, N. A.; Aksenov, D. A.; Nadein, O. N.; Rubin, M. RSC Adv. 2017, 7, 29927-29932. doi:10.1039/c7ra04751g

44. Aksenov, A. V.; Aksenov, N. A.; Arutiunov, N. A.; Malyuga, V. V.; Ovcharov, S. N.; Rubin, M. RSC Adv. 2019, 9, 39458-39465. doi:10.1039/c9ra08630g

45. Aksenov, A. V.; Khamraev, V.; Aksenov, N. A.; Kirilov, N. K.; Domenyuk, D. A.; Zelensky, V. A.; Rubin, M. RSC Adv. 2019, 9, 6636-6642. doi:10.1039/c9ra00976k 
46. Aksenov, N. A.; Arutiunov, N. A.; Kirillov, N. K.; Aksenov, D. A.; Aksenov, A. V.; Rubin, M. Chem. Heterocycl. Compd. 2020, 56, 1067-1072. doi:10.1007/s10593-020-02775-5

47. Aksenov, N. A.; Aksenov, A. V.; Kirilov, N. K.; Arutiunov, N. A.; Aksenov, D. A.; Maslivetc, V.; Zhao, Z.; Du, L.; Rubin, M.; Kornienko, A. Org. Biomol. Chem. 2020, 18, 6651-6664. doi:10.1039/d0ob01007c

48. Klingele, M. H.; Moubaraki, B.; Murray, K. S.; Brooker, S. Chem. - Eur. J. 2005, 11, 6962-6973. doi:10.1002/chem.200500387

49. Huhti, A.-L.; Gartaganis, P. A. Can. J. Chem. 1956, 34, 785-797. doi:10.1139/v56-102

50. Uhlig, F. Angew. Chem. 1954, 66, 435-436. doi:10.1002/ange.19540661503

51. Lyapchev, R.; Petrov, P.; Dangalov, M.; Vassilev, N. G. J. Organomet. Chem. 2017, 851, 194-209. doi:10.1016/j.jorganchem.2017.09.036

52. Zhao, Q.; Liu, S.; Li, Y.; Wang, Q. J. Agric. Food Chem. 2009, 57, 2849-2855. doi:10.1021/jf803632t

53. Vu, T. Y.; Chrostowska, A.; Huynh, T. K. X.; Khayar, S.; Dargelos, A.; Justyna, K.; Pasternak, B.; Leśniak, S.; Wentrup, C. Chem. - Eur. J. 2013, 19, 14983-14988. doi:10.1002/chem.201301663

54. Winterfeld, K.; Franzke, H. Angew. Chem. 1963, 75, 1101-1102. doi:10.1002/ange.19630752209

\section{License and Terms}

This is an Open Access article under the terms of the Creative Commons Attribution License (https://creativecommons.org/licenses/by/4.0). Please note that the reuse, redistribution and reproduction in particular requires that the authors and source are credited.

The license is subject to the Beilstein Journal of Organic Chemistry terms and conditions:

(https://www.beilstein-journals.org/bjoc)

The definitive version of this article is the electronic one which can be found at:

https://doi.org/10.3762/bjoc.16.239 